\title{
Smith W. Brookhart and the Limitations of Senatorial Dissent
}

\author{
RONALD F. BRILEY
}

Social SCIENTISTS have recognized that legislatures are complex institutions in which formal written or verbalized rules are not the only dictates of proper behavior. Many scholars have pointed out that certain informal rules or norms may have even a greater influence upon behavioral expectations than do articulated guidelines. One political science study defines legislative norms as "widely shared sets of beliefs regarding appropriate behavior for legislators as legislators where these beliefs are not only shared but believed to be shared by legislators and are supported by social mechanisms encouraging conformity." Certainly the concept of legislative norms applies to one of America's most esteemed political institutions, the U.S. Senate, and there "social mechanisms encouraging conformity" may hinder the senator who flouts such norms. The stormy political career of self-confessed Republican insurgent Smith W. Brookhart, who served as a U.S. senator from lowa in the 1920 s, illustrates some of the limitations to dissent which legislative norms can construct in the Senate. ${ }^{1}$

One influential study enumerates Senate "folkways," those unarticulated forces which combine to enforce group pressure. The first rule of Senate behavior is that "new members are expected to serve a proper apprenticeship." Senatorial adherence to an unobstructive apprenticeship is essential for future effectiveness in the institution. In addition, institutional folk-

1. F. Ted Herbert and Lelan E. McLemore, "Character and Structure of Legislative Norms: Operationalizing the Norm Concept in the Legislative Setting," American Journal of Political Science 17 (August 1973), 506-527, quotations from p. 508. 
ways require that senators devote most of their energies to legislative routine rather than to publicity-seeking activities. The effective senator is also to develop a legislative speciality as one cannot reasonably deal with a wide range of complex issues. Finally, senatorial folkways emphasize comradeship, including such attributes as courtesy, to insure that political disagreements do not influence personal feelings; reciprocity, to encourage senators to assist each other whenever possible by exchanging votes and support; and intense institutional patriotism, to maintain morale. While senators' folkways are necessary for the Senate to function as a lawmaking body, they "are not universally accepted or adhered to; indeed there is some covert hostility toward them in certain circles." Among the factors which can influence a senator to accept or reject Senate folkways are previous training and experience; political ambition; a competitive two-party, or a large and complex, constituency; and political ideology. Thus, a senator elected "as a 'liberal' or 'progressive' or 'reformer' is under considerable pressure to produce legislative results in a hurry. The people who voted for him are not likely to be happy with small favors-dams built, rivers dredged, roads financed-but want major national legislative policy changed." A senator may well disregard these influences toward nonconformity and adhere to the Senate folkways, not necessarily from coercion, but perhaps because the basis for evaluating a senator's effectiveness is the ability to get one's bills passed. Senators who conform to the folkways get more of their proposed legislation enacted. Thus, in the famous maxim of Sam Rayburn, "to get along, you have to go along." 2

Another study of Senate behavior contends that to be a member of the "inner club" senators must give special consideration to the institution's informal norms and procedures. The effective senator is therefore a master of conciliation and an advocate of institutional patriotism. Those that challenge Senate folkways and norms "are in the end influential only to the degree that they may so instruct or so inflame a part of the public sufficiently large to insist upon this or that course of

2. Donald R. Matthews, U.S. Senators and Their World (Chapel Hill, 1960), 92-117. 
political conduct. The Senate type in the last analysis has the better of it. For not only does his forum generally resist change and all public pressure save the massive and the enduring; it also will tend quickly to adopt his proposals unless they are quite clearly untenable." Thus the price paid for defying Senate norms may be legislative ineffectiveness. The Senate is, however, basically a very tolerant institution reluctant to undertake punitive measures against its members. It moved slowly to censure Senator Joseph $\mathrm{McCarthy}$ for bringing the institution into dishonor and disrepute, for example. Open censure is a departure from the Senate norms of more subtle coercion and cooperation toward legislative effectiveness. ${ }^{3}$

A case study of Wisconsin Senator William Proxmire argues that an alternative outsider role exists in the Senate for the political maverick. Such individuals consciously choose to disregard institutional norms which interfere with their ideological and reelection goals. The Senate has even officially acknowledged the historical importance of the outsider. A Senate committee formed in 1955 to designate five outstanding historical members of the institution made Robert M. LaFollette of Wisconsin one of its selections, thus recognizing the liberal maverick in the annals of the Senate. Bills enacted may be too narrow a test of legislative effectiveness, as the Senate is not a place "where the individual members are paid on a piece-work basis." The outsider's presentation of unpopular or minority views contributes to the important process of conflict resolution as well. Therefore "the behavior of the Senate type who is in the Inner Club may be functional for groups who benefit from preserving the status quo, dysfunctional for conflict resolution in the larger society. The behavior associated with the Outsider may be functional for protest groups seeking a spokesman, dysfunctional for groups needing leverage inside the legislative body." The outsider tends to look to a constituency and ideological allies for norms rather than to the other members of the Senate, and historically Senate dissenters have won reelection. They may be able to defy folkways and norms because the Senate can be tolerant of individualistic behavior,

3. William S. White, Citadel: The Story of the U.S. Senate (New York, 1956), $88,127$. 
while "the imposition of censure or ostracism is a rare and traumatic action reserved for really deviant behavior, borne a long time." What constitutes "really deviant behavior," and what causes Senate norms to come into play, however, remain variable. ${ }^{4}$

A detailed examination of the turbulent political career of Iowa Senator Smith W. Brookhart reveals some of the limitations of senatorial dissent and the role which the outsider can play. Brookhart was one senator who defied institutional folkways and who apparently suffered Senate punishment for his actions. In 1920 Brookhart opposed incumbent Senator Albert B. Cummins in the Republican primary and lost, but in 1922 he won election to fill the unexpired term of Senator William Kenyon who had retired from the Senate to accept a federal judgeship. In 1924 Brookhart apparently won election to a full term in the Senate, but the Republican caucus dismissed him in 1925, and in 1926 the Senate overturned his victory. He immediately returned to Iowa, defeated Cummins in the Republican primary, and returned to the Senate in November of 1926. His political career finally ended with defeat in the 1932 Republican primary. ${ }^{5}$

Brookhart's maverick style did not originate in the Senate. Rebellion seemed to be part of his character as well as his politics, and he delighted in telling reporters about his middle name: "Wildman is a good name. It is my mother's name; it is English. But is also notice to the stand-patters that I am one Progressive who won't be tamed." He was born in Scotland County, Missouri, on February 2, 1869, allegedly in a log cabin. His family moved to Iowa in 1879, and he attended Iowa schools until he graduated from Southern Iowa Normal School in 1889. He first earned his living by teaching, while he studied law at night under the guidance of Dillon Payne, brother-inlaw of former Populist presidential candidate James B. Weaver. After passing the state bar examination in 1892, Brookhart

4. Ralph K. Huitt, "The Outsider in the Senate: An Alternative Role," American Political Science Review 55 (Spring 1961), 566-575, quotations from pp. 572-575.

5. For a detailed account of Brookhart's election activities in the 1920 s see Jerry A. Neprash, The Brookhart Campaigns in Iowa, 1920-1926 (New York, 1932). 
moved to Washington, Iowa, where he soon became active in politics. He naturally adhered to the Republican party, which was popular among Iowans who still identified with the legacy of Abraham Lincoln and the Civil War, and many of whom were G.A.R. veterans. Claiming that he was a prohibitionist "from his mother's breast," Brookhart served three terms, from 1894 to 1900 , as Washington County Attorney on a platform dedicated to the enforcement of prohibition law. ${ }^{6}$

Brookhart next set his sights on a congressional seat, but, unfortunately for his political prospects, he was unable to reach an accommodation with Joseph $W$. Blythe. Blythe was the political representative of the Burlington Railroad which dominated politics in the First Congressional District. Brookhart maintained that he left Blythe's office "determined to fight the railroads and drive them out of politics." He thus aligned himself with the progressive forces of Governor Albert Cummins. Yet this affiliation did not advance his political career, as in 1910 he lost the Republican primary contest for the First Congressional District. Frustrated in his political endeavors, Brookhart turned to journalism, and purchased the Washington County Press in December of 1911. As a progressive editor, he announced in 1912 that he would vote for the Bull Moose candidate, Theodore Roosevelt, but he would not join the Progressive party as he believed Republicans could reform their party to be progressivism's vehicle. Nevertheless, he generally downplayed the subject of party regularity: "The doctrine of standing by party if party is wrong, is dead."7

6. Ray Tucker and Frederick R. Barkley, Sons of the Wild Jackass (Boston, 1932), 344. While no biography of Brookhart exists, the most detailed accound of his life and career is Ray S. Johnston, "Smith Wildman Brookhart: Iowa's Last Populist" (M.A. thesis, State University of Iowa, 1964). Brief but useful overviews of Brookhart include Reinhard H. Luthin, "Smith Wildman Brookhart of Iowa: Insurgent Agrarian Politician," Agricultural History 25 (October 1951), 187-197 and George William McDaniel, "Smith Wildman Brookhart," Palimpsest 63 (September/October 1982), 175-183. See also George William McDaniel, "Prohibition Debate in Washington County, 1890-1894: Smith Wildman Brookhart's Introduction to Politics," Annals of Iowa 45 (Winter 1981), 519-536.

7. James B. Morrow, "A Hunter of Wall Street Devils," Nation's Business 12 (March 1923), 21-22; Washington County Press, 11 January 1912. 
BROOKHART first indicated that he was becoming restless as a regular Republican in 1920 when he challenged his former mentor Cummins in the Republican senatorial primary. Brookhart, along with organized labor in the state, was upset with Cummins' sponsorship of the Esch-Cummins Act. This act returned the railroads to private ownership after World War I with what many farmers and laborers considered to be a too generous guarantee of railroad profits. Brookhart argued that the law was "a surrender of most of the reforms we have fought for during the past twenty years." He seemed to assume an outsider posture in this campaign. He portrayed Cummins as a former progressive who had sold out to the railroads, while Cummins controlled the party machinery so that he could prevent Brookhart from speaking at the Republican state convention. In a hotly contested primary, Cummins still prevailed 115,768 to 96,563 . In 1920 , Iowa voters were not prepared to send the message to the nation that they chose an outsider as their representative. ${ }^{8}$

This spirit changed in 1922. Overexpansion of American agriculture during World War I in response to the slogan "food will win the war," and the postwar decline of European markets, contributed to a major agricultural depression in Iowa and throughout America's farmland. Iowa began to feel the impact of this depression in July of 1920, only one month after Brookhart's defeat in the Republican primary. Land values had risen spectacularly with the expectation that high farm incomes would continue throughout the 1920 s. The percentage of land mortgaged in the state rose from 38 percent in 1915 to 51 percent in 1924, while the debt per acre increased from $\$ 54.00$ in 1915 to the exorbitant figure of $\$ 100.00$ per acre in 1921. The agricultural depression made payment of many mortgages impossible. Corn, the staple of lowa farmers, declined from a selling price of $\$ 1.20$ per bushel in 1919 to a disastrous $\$ .30$ per bushel by December 1921 . This price collapse affected almost all state farm commodities. In terms of income, grain declined 53 percent; hogs, 39 percent; and cattle, 30 percent, between September of 1920 and December of 1921. Governor N. C. Kendall recognized the possible political repercussions

8. Washington Evening Jourial, 31 March 1919. 
of the Iowa farmers' economic plight and complained to fellow Iowan and Secretary of Agriculture Henry C. Wallace: "The people of lowa are wholly dissatisfied with existing conditions, and unless substantial relief is afforded, the political revolution of 1920 will be remembered as a zephyr compared to the tornado which will occur in 1922."9

Smith Brookhart was in a position to avail himself of the political tornado which Governor Kendall predicted. On January 31,1922, President Harding appointed Iowa Senator William Kenyon, the leader of the farm bloc, to a federal judgeship, which gave Brookhart another opportunity to claim an Iowa seat. Governor Kendall appointed Charles Rawson, the state chairman of the Republican party, to replace Kenyon in the Senate until November when elections could occur, on the condition that Rawson would not be a candidate to succeed himself. Brookhart and three more conservative opponents were early entrants into the race for the Republican nomination. In the midst of the crisis, Brookhart emphasized economic questions by proposing cooperative marketing, repeal of the Esch-Cummins Act, changes in the Federal Reserve System which he contended had been unfair to the farmer, and payment of a soldiers' bonus. Brookhart generally assaulted the vested interests of wealth and what he termed "the non-partisan league of Wall Street." LaFollette's Magazine endorsed the Iowa insurgent in glowing terms, as "a man of sterling character and splendid ability. The frank declaration of his platform upon the issues of the day reflect [sic] his life-long service to the cause of the common people." Brookhart appeared to be constituency-oriented like LaFollette, willing to play the alter-

9. For the most detailed secondary account of the agricultural crisis consult U.S. Congress, The Agricultural Crisis and Its Causes: Report of the Joint Commission of Agricultural Inquiry, House Report 408, 67th Cong., 1st sess., 1921. For the impact of the agricultural depression on Iowa see Leland L. Sage, "Rural Iowa in the 1920s and 1930s: Roots of the Farm Depression," Annals of Iowa 47 (Fall 1983), 91-103; Dorothy Schwieder, "Rural Iowa in the 1920s: Conflict and Continuity," Annals of Iowa 47 (Fall 1983), 104-115; and Joseph F. Wall, "The Iowa Farmer in Crisis, 1920-1936," Annals of Iowa 47 (Fall 1983), 116-127. For statistical information see Earle D. Ross, Iowa Agriculture (Iowa City, 1951), 153-154; U.S. Department of Agriculture, Agricultural Yearbook, 1922 (Washington, D.C., 1923), 574. See also N. C. Kendall to Henry C. Wallace, 17 June 1921, General Records of the Department of Agriculture, Record Group 16, National Archives, Washington, D.C. 
native role of the outsider and present unpopular or minority views necessary for conflict resolution. ${ }^{10}$

Despite the favorable economic climate for a protest candidate, Brookhart was clearly worried about his electoral prospects. He wrote to LaFollette for aid in gaining the Iowa Farm Bureau's support and warned: "Thirty-five percent of the vote is required to nominate. The plan of the other side is to bring out so many candidates I will not get the $35 \%$." If no candidate surpassed the all-important 35 percent plateau, the Republican state convention would decide the nomination, and there the political outsider would have little chance of achieving party endorsement. Brookhart's fears seemed realized when Clifford M. Thorne, his former supporter and a foe of the railroads, made a late entry into the race. Dante M. Pierce, publisher of the Iowa Homestead, complained that Thorne's sole purpose was to divide the progressive farm vote and deny Brookhart the nomination. Pierce called Thorne a Judas and a tool of Wall Street. Brookhart, meanwhile, asserted that all of his opponents were reactionaries. "They are like a can of fish worms, all scrambling to dig in and crawl out of sight, but they are all bait for the same hook - the nonpartisan league of Wall Street," he proclaimed. ${ }^{11}$

The strategy of Brookhart versus the field apparently worked as the insurgent shocked many observers who had assumed that the party convention would settle the nomination. Brookhart gained 41 percent of the vote, while Thorne ran a distant second. Brookhart's advocacy on behalf of disgruntled farmers had brought his additional support in the cash-grain areas of northwestern Iowa, and he had retained his labor backing. Of the eleven Iowa counties in which he showed the greatest vote increase over 1920, seven were in the cash-grain region. Iowa

10. For an examination of the politics in Kenyon's nomination see Robert K. Murray, The Harding Era (Minneapolis, 1969), 217. See also Des Moines Register, 19 April 1922; "Iowa and the U.S. Senate," LaFollette's Magazine (April 1922), 55, as cited in "Speeches and Writings" file, Robert M. LaFollette, Sr. Papers, Library of Congress, Washington, D.C. (hereafter file name, LaFollette, Sr. Papers).

11. Smith W. Brookhart to Robert M. LaFollette, Sr., 1 March 1922, "Special Correspondence," LaFollette, Sr. Papers; Iowa Homestead, 11 May 1922, as cited in "Special Correspondence: Dante M. Pierce," LaFollette, Sr. Papers; Des Moines Register, 23 May 1922. 
farmers were in revolt. But Brookhart's candidacy remained an anathema to the state Republican party, and the old guard in control of the August convention repudiated Brookhart by enacting an almost reactionary platform. It endorsed Cummins while ignoring Brookhart, asked for a repeal of the primary law, and included a provision which criticized demagogues who encouraged class conflict, an obvious reference to Brookhart. It was all the state chairman and Senator Rawson could do to prevent the platform committee from endorsing the EschCummins Act. ${ }^{12}$

Brookhart surprised some of his supporters by turning the other cheek when the party convention snubbed him. He made light of this treatment claiming, "in fact, the Republican convention had so much confidence in me and were so satisfied with my record that they wouldn't even take the time to listen to me. They thought it would be a waste of valuable time." Brookhart apparently valued the party label in 1922 in the solid Republican state of Iowa. Yet while he stayed in the party fold, some Republicans refused to support him. By October 16, however, Dante M. Pierce informed LaFollette that the party bolt in Iowa was defused. Pierce did "not mean to say there will not be Republican votes against Brookhart, but for every Republican vote he loses he will get three Democratic votes." Pierce's prediction was not far wrong, as Brookhart swept by his Democratic opponent Clyde Herring with a majority of over 160,000 votes. $^{13}$

Although Brookhart won election as a Republican, the national press was quick to perceive his victory as the elevation to national office of a man who would play political outsider in Washington to champion the cause of his rural constituency. Current Opinion said Brookhart would enter the Senate "to represent a constituency whose usual garb is overalls and cowhide boots, in the effort to get for these downtrodden and uncoddled elements the legislation necessary for their welfare

12. Corwin D. Cornell, "Smith W. Brookhart and Agrarian Discontent in Iowa" (M.A. thesis, University of Iowa, 1949); Des Moines Register, 3 August 1922.

13. Dés Moines Register, 24 August 1922; Dante M. Pierce to Robert M. LaFollette, Sr., 16 October 1922, "Special Correspondence: Dante M. Pierce," LaFollette, Sr. Papers. 
and not to attend teas and dances." The New York Times ridiculed Brookhart's victory and the distressed farmers' plea for government relief as "the result of that combination of selfish interests against the common interest which has been lamentably illustrated of late in Washington." With commodity prices continuing to decline, the farm press, however, was not liable to see the oowa election as a manifestation of selfish interests drinking at the public trough. The Prairie Farmer editorialized that farmers who elected Brookhart, or other mavericks such as Lynn J. Frazier of North Dakota and Henrik Shipstead of Minnesota, to the Senate in 1922 were not irrational. They were sending a message to the Harding administration that they were growing restive without a positive government response to their distress. The Prairie Farmer concluded: "the farmers aren't going red, nor are the rest of the folks who helped spill the beans election day. They want some place to sell their corn, and they don't like the price of coal. That's about all there is to it. They believe a few men in Washington who could see over the Allegheny mountains might help." Farmers were not seeking representatives who would master the folkways and norms of the Senate, but those who would "raise hell" and draw attention to their plight: in short, the outsiders. ${ }^{14}$

Established interests could still hope that Brookhart, like many other champions of the people's interests, would recant on his campaign promises and style once he reached the Senate. Senate leaders, suspicious of the Iowa insurgent, also tried to muzzle Brookhart through his committee assignments. They appointed him to low-prestige committees: Claims, Education and Labor, Interoceanic Canals, Manufactures, and Military Affairs. These committees did not represent major federal government concerns in the 1920s. In his electoral campaign Brookhart had primarily addressed himself to the problems of agriculture and exorbitant transportation rates, but these assignments had little to do with such issues. To conform to Senate practice, Brookhart should have assumed an unob-

14. "Congress Has a Shouting Progressive in Brookhart of Iowa," Current Opinion 74 (May 1923), 538; New York Times, 8 June 1922; Prairie Farmer, 18 November 1922. 
structive apprenticeship by accepting these assignments and limiting his activities to areas of legislation within the jurisdiction of these committees. Such dedication to Senate norms would supposedly result later in better appointments after Brookhart had completed his apprenticeship. ${ }^{15}$

Brookhart preferred to defy Senate norms. He had little choice. A disgruntled rural constituency, which felt that the national government had ignored it, elected him to air its plight, good and loud. Brookhart had only two years in which to gain this attention as he would have to face reelection in 1924. The immediacy of another Brookhart campaign was evident to Dante M. Pierce, as he asked that prototypical outsider, Robert LaFollette, to help Brookhart get accustomed to the Senate and the Washington political scene: "I would feel more sanguine about the situation if he had been elected for a six year term rather than two years and three months, but I have confidence in his ability to handle himself so that he can be returned in two years." With the time constraints on Brookhart to draw attention to his rural electorate's problems, his admirers expected him to promptly challenge Senate folkways and assume the role of what Austin Haines in the Nation would call "the Dissenter." "Colonel Brookhart is the voice of discontent, in the hearts of Iowa farmers and organized labor," Haines asserted, "against wrongs which they believe they have suffered at the hands of the present administration. He is an indefatigable worker, firm to the point of stubbornness, a hard hitter, who takes himself with the utmost seriousness, and has not a particle of fear in his make-up."16

Brookhart lost little time. One of his first actions in the Senate was to help block consideration of President Harding's pet project, a ship subsidy, in order to obtain attention for agricultural relief measures. Needless to say, such disregard for the Republican president's desires by a freshman senator of the party did not sit well with the Republican majority in the Senate. The New York Times, close to many key Republican

15. Congressional Record, 68th Cong., 1st sess., 1923-1924, 65:156.

16. Dante M. Pierce to Robert M. LaFollette, Sr., 14 November 1922, "Special Correspondence: Dante M. Pierce," LaFollette, Sr. Papers; Arthur Haines, "Smith W. Brookhart, Dissenter," Nation 115 (November 1, 1922), 467. 
sources, ridiculed Brookhart's activities: "In almost the same breath, he shudders at a subsidy for the merchant marine and demands a subsidy for the never-enough-to-be-prized-andprivileged farmers." But Brookhart was no fool. Neither President Harding nor Republican senators would be among those reelecting him in 1924. He needed the support of agrarian rather than maritime interests and the ship subsidy was not popular back on the farm. The Prairie Farmer editorialized that the government should put it aside until agricultural relief was available. "Prosperous, contented farmers are of more importance to the nation's welfare in peace and its safety in war than all the ships we can build," reminded the Prairie Farmer. ${ }^{17}$

Brookhart's opposition to the ship subsidy was not an aberration. The freshman senator continued to speak out on a wide range of issues. He vigorously assailed the Esch-Cummins Act and its guarantee of a 6 percent return on railroad investments as unfair to the farmers of America. Brookhart maintained that "the guarantying of a half billion dollars to 8,000 millionaires to keep full the measure of their war profits is a wise, businesslike, conservative, and patriotic use of the Public Treasury, but the guarantying of the cost of production to 7,000,000 farmers for a crop produced at the command of their government at the oppressive cost of war prices is unwise, socialistic, and treasonable." Brookhart's diatribes against Esch-Cummins often took on a very bitter and personal tone which seemed to flout the Senate norms of courtesy and reciprocity. After all, the act's sponsor was the well-respected president pro tempore and powerful chairman of the Interstate Commerce Committee, the senior senator from Iowa, Albert Cummins. Brookhart also ignored the folkway of legislative specialization. He proposed an excess profits tax and increased taxation for the wealthy, and demanded farmer representation on the Federal Reserve Board. He argued that the board was responsible for the deflation and price collapse of 1920 and yet agriculture, which furnished 40 percent of the nation's bank deposits, had no representation on it. But these were not concerns directly relevant to his committee assignments. ${ }^{18}$

17. New York Times, 20 December 1923; Prairie Farmer, 2 December 1922.

18. Congressional Record, 67th Cong., 4th sess., 1922, 64:621; Congressional Record, 68th Cong., 1st sess., 1924, 65:1,083, 8,025-8,027. Some historians 
COOPERATIVE marketing was Brookhart's panacea for the plight of American agriculture, and he loved to educate his listeners on his favorite subject. He observed that cooperatives were "more enterprising than private business; they are more progressive; they are more philanthropic; they do everything in the spirit of the advancement of human civilization better than the corporations ever have done anywhere in the world." This admiration for the cooperative system often antagonized Brookhart's colleagues and made him the subject of political controversy and publicity. In February of 1923, he suggested in a New York speech that Congress prohibit all interstate commerce not conducted under federal charter and the cooperative movement. Senator Irving Lenroot of Wisconsin labeled this proposal as class legislation similar to that of the Russian Bolsheviks. Lenroot charged that not even Lenin would think of advocating such a plan. Comparison with Lenin would become familiar to Brookhart, especially after he returned from a journey to Russia, made ostensibly to investigate the cooperative movement there. Again violating the norm against freshman senators seeking publicity, Brookhart was certain to gain attention when he claimed the Soviet government was stable and had "abandoned the communistic plan for that of the cooperative." He called upon Secretary of State Charles Evans Hughes to extend American recognition to the Soviet Union and immediately provoked a shower of criticism. Senator Cummins declared, "If his powers were commensurate with his apparent desires, the government would not last a fortnight."19

In addition to breaking with the Senate folkways of no publicity seeking, freshman inactivity, and legislative specialization, Brookhart did not develop a sense of comradeship with many of his colleagues. He chastised Senator David A.

have challenged the assertions which farm representatives such as Brookhart made against the Federal Reserve Board. For a refutation of Bookhart's views see Arthur S. Link, "The Federal Reserve Policy and the Agricultural Depression of 1920-1921," Agricultural History 20 (July 1946), 166-175.

19. Congressional Record, 67th Cong., 4th sess., 1922, 64:2,766; New York Times, 2 February, 19 July 1923; Des Moines Register, 18 July 1923. For more detailed examinations of Brookhart's journey to Russia see Ronald F. Briley, "Smith W. Brookhart and Russia," Annals of Iowa 42 (Winter 1975), 541-556 and Smith Wildman Brookhart, "What I Really Saw and Learned in Europe in 1923," Saturday Evening Post 202 (15 March 1930), 23, 165-169. 
Reed of Pennsylvania for expressing ignorance about the farm bloc, and warned Reed that if he did not learn more of their plight, the farmers of Pennsylvania would soon find someone to replace him in the Senate. An avid prohibitionist, Brookhart also publicly lectured his colleagues on their drinking habits; he charged flasks containing alcoholic beverages were in evidence at many Washington parties. Such allegations would certainly never make Brookhart a member of the "inner club." 20

Smith Brookhart, because of constituency concerns and the desire for reelection, had chosen to fill the role of outsider in the Senate. In his legislative activities and publicity seeking he had been true to his campaign rhetoric of 1922 . "I belong to the farmer class. I have never risen above it. I have no ambition to rise above it. I have a feeling of the deepest class consciousness. ... I am opposed to arraying class against class, but I am a thousand times more opposed to arraying class over class," Brookhart proclaimed. With him in the Senate, farmers had an advocate who made sure their voice of protest was heard. This type of behavior received no formal reactions from the Senate other than considerable complaining and personal criticism. Normally, only the voters of Iowa could render an electoral verdict on Brookhart's defiance of legislative norms. In his 1924 reelection campaign, however, Brookhart faced a controversy that would allow his fellow senators to pass judgment on him..$^{21}$

Initially Brookhart's strategy seemed successful. He easily won renomination as the Republican senatorial candidate. Again the Republican state convention ignored him, and moreover, in an obvious reference to Brookhart, the delegates adopted a resolution which condemned socialists and demagogues. This time the maverick Republican refused to bear such slights silently and he pushed his insurgency beyond the bounds which many Iowans could accept. Robert LaFollette's thirdparty presidential candidacy, which Brookhart predicted would carry the state by 150,000 votes, encouraged Brookhart while reports that Secretary of the Treasury Andrew Mellon had

20. Congressional Record, 67th Cong., 4th sess., 1923, 64:2,771; Tucker and Barkley, Sons of the Wild Jackass, 360-361.

21. Des Moines Register, 5 September 1922. 
intervened to deny Iowan William Kenyon the Republican vice-presidential nomination angered him. So Brookhart decided to challenge the Republican party leadership. On October 1,1924, in a public letter to William Butler, chairman of the Republican National Committee, Brookhart demanded resignation from the Republican vice-presidential nominee Charles G. Dawes and called for a different candidate of a more progressive vein. He followed this outcry with a speech on October 3 in Emmetsburg, Iowa, in which he declared: "I belong to the farm bloc. President Coolidge belongs to the Wall Street bloc." Brookhart maintained that the state Republican convention, which the "Coolidge machine". had dominated, had snubbed and insulted him. Furthermore, while he continued to carry forth the traditional Republican principles of Lincoln, Roosevelt, and Kenyon, reactionary forces, contrary to the true nature of Republicanism, had gained control of the party. The "issue has now arisen in lowa as to whether the principles of the Republican Party shall be determined by the voters themselves or by a small group of crooked and irresponsible dictators set up by the nonpartisan league of Wall Street." His rural constituency had allowed Brookhart to question Senate norms; now he hoped it would support his challenge to party discipline. ${ }^{22}$

Although his repudiation of Coolidge was not an automatic endorsement of LaFollette's candidacy, the LaFollette headquarters in lowa did book Brookhart's speeches for the duration of the campaign. The Republican State Central Committee reacted to Brookhart's actions by withdrawing organized support for his candidacy. The committee maintained that Brookhart had bolted the party at the LaFollette camp's urging as part "of a conspiracy to defeat the right of the people to elect a President at the polls, and to force such an election by a Congress selected two to six years ago." Many Republican newspapers in the state advised their readers to vote for the Democratic candidate, Daniel Steck, by publishing sample bal-

22. Des Moines Register, 13 June, 23 July 1924; Senate Committee on Privileges and Elections, Senator from Iowa: Hearings Before a Subcommittee on Privileges and Elections on Senate Resolution 21, 69th Cong., 1st sess., 1925-1926, 72, 99-101 (hereafter Committee on Privileges \& Elections, number). 
lots with an arrow drawn to Steck's name. Brookhart overestimated both LaFollette's appeal and the radicalism of Iowa voters. Contrary to many predictions, LaFollette lost Iowa's electoral votes; they remained in the Republican column. A temporary increase in farm prices, the Iowa voter's traditional Republicanism, opposition from the Republican Service League, and LaFollette's continuing emphasis on the somewhat outdated cause of fighting monopolies, all contributed to the Wisconsin progressive's failure. In his senatorial contest, Brookhart was victorious by the very slim margin of approximately seven hundred votes. His party "bolt" had evidently alienated Republican voters who had remained loyal throughout his highly irregular conduct in the Senate. ${ }^{23}$

Republicans in the Senate, who had suffered through two years of Brookhart's antics without applying sanctions, voted to exclude Brookhart, along with LaFollette and Senators Lynn J. Frazier and Edwin P. Ladd of North Dakota, from further party conferences, in addition to withdrawing their committee appointments. Being read out of the senatorial Republican party proved to be only the beginning of Brookhart's difficulties. Steck, the defeated Democratic senatorial candidate, petitioned the Senate to challenge Brookhart's election. The body referred the petition to the Committee on Privileges and Election for hearings. In his complaint, Steck argued that under Section Five, Article One of the Constitution each house of Congress "shall be the judge of the elections, returns, and qualifications of its own members." He maintained that many voters placed an " $X$ " on the Republican column and then drew an arrow to Steck's name in the Democratic column. Although the ballots were marked inaccurately according to Iowa election law, Steck asserted that the committee should strictly endorse the intent of the voters. B. B. Burnquist, chairman of the Republican party in Iowa, also filed a complaint which contested Brookhart's election. According to Burnquist, the

23. Committee on Privileges \& Elections, 102-103. For an extensive examination of the LaFollette campaign see Kenneth MacKay, The Progressive Movement of 1924 (New York, 1947). For the role of the Republican Service League see George W. McDaniel, "Over Here: The Mobilization of the Republican Service League to Defeat Smith Wildman Brookhart" (M.A. essay, University of Iowa, 1977) and New York Times, 18 April 1926. 
senator had claimed to be a Republican until his Emmetsburg speech, when he openly repudiated the Republican party, and it was then too late'to remove Brookhart's name from the ballot. Burnquist claimed that Brookhart had attempted to defraud the Republican voters of Iowa by denying them a candidate. Burnquist concluded his protest with a bombastic flourish: "Never have the voters been so shamefully and unfairly betrayed. Never before has the entire membership of a political party been disfranchised. The false pretense and deception of the incumbent has shocked the people of Iowa and the nation." 24

In response to these allegations, Brookhart insisted that his election had been fair according to Iowa law. He had campaigned on the platform which the state Republican convention had adopted and was a Republican true to the historical principles of Lincoln and Roosevelt, while the State Central Committee had repudiated the party platform and conspired to defeat him. He again enunciated his constituency orientation: "he [had] announced his platform distinctly and definitely upon every issue and [had] submitted it openly to the Republican voters of Iowa." Brookhart's arguments did not persuade the Committee on Privileges and Elections; it voted ten to one to uphold Steck's petition and unseat Brookhart. The committee's chairman, Richard P. Ernst of Kentucky, denied that the committee had decided the issue politically. It had counted ballots for Steck, which while inaccurately marked according to Iowa election law had nevertheless shown intent to vote for the Democratic candidate, and these votes gave Steck a majority in the election. Ernest did concede that many Iowans scratched their Republican votes for Steck in response to the campaign efforts of the Republican state organization and press in Iowa. The voters of Iowa intended to punish Brookhart for his part "bolt."25

Despite Ernst's assertions that political and personal considerations were not part of the committee's decision, some evidence suggests otherwise. For example, Arkansas Senator T.

24. Congressional Record, 68th Cong., 2nd sess., 1925, 66:1,285; Committee on Privileges \& Elections, 1, 38.

25. Committe on Privileges \& Elections, 41; Congressional Record, 69th Cong., 1st sess., 1926, 67:6,950. 
H. Caraway's opening remarks in the Senate chamber on the Brookhart-Steck question revealed the pressures at work.

There has been propaganda going the rounds of the Senate. Its propriety I shall not undertake to discuss. One party to the contest has gone to every Senator on this floor personally and set out his views. He has gone not only one time, but, I presume, every Senator on the floor has been approached many times and had that party to this contest state what his views are and what he claims his rights were. There has been constant propaganda. I myself was subjected to it. I do not personally know what propriety demands. I do know that the other party to this contest has never gone to a single member of the body, as far as my information goes-I know it is true so far as I am individually concerned-he has never suggested one thing that should be done or should not be done in determining this contest. In fact so particular was he that he never, as I understand, was introduced to a single member of the Senate. Which was the course that propriety ought to suggest? I am going to leave each Senator to be his own judge.

Thus Caraway reminded his colleagues of Brookhart's aggressive behavior and flouting of Senate norms. ${ }^{26}$

Midwestern progressives and some southern Democrats defended Brookhart. Cole Blease of South Carolina asserted that unseating Brookhart would be a violation of states' rights. Blease argued, "If he has come here wrongly, four years from now the people of Iowa will pass on that and our hands will be clean." Many Senators most wanted to hear the views of the senior senator and president pro tempore, Albert Cummins. In reply to allegations that he was behind the move to unseat Brookhart, who had long been a thorn in his side, Cummins insisted that the Senate should decide the contest on its merits. Cummins persisted: "I have not attempted, either directly or indirectly, by discussion, suggestion, inference, or any other manner to influence any Senator with regard to this contest." While he certainly had reason to view favorably the abrasive Brookhart's departure from the Senate, such a turn of events

26. Congressional Record, ibid., 6,860 . 
would be a mixed blessing for Cummins, as an unseated Brookhart would probably return to Iowa and challenge him in the 1926 primaries. ${ }^{27}$

With Cummins abstaining, sixteen Republicans joined twentynine Democrats to award the contested Iowa seat to the Democrat, Daniel Steck. The Republican party would maintain a fifteen-seat majority without the troublesome Brookhart. He had defied Senate folkways and had assumed the role of a political outsider; accordingly, he had accumulated little personal collateral with his colleagues. As journalists Ray Tucker and Frederick Barkley concluded, Republicans "preferred a conservative Democrat to a radical Republican." The New York Times, never a great admirer of Brookhart, bid good riddance to him and praised the Senate action: "In any event, he has had a severe lesson, and party discipline will be strengthened by the exclusion of a Senator who flouted the very party of which he sought the support." George Norris, who became the leader of the Senate progressives after Robert LaFollette died in 1925, also asserted that Brookhart's progressive position cost him his Senate seat. He informed N. Baker of Muscatine that after an honest election, the Senate illegally threw Brookhart out of office under the manipulations of Massachusetts Senator William Butler, chairman of the Republican National Committee. Norris concluded, "I think it is well known that quite a number of Senators voted against Brookhart without giving any consideration whatsoever to the evidence." Norris endorsed Brookhart's decision to return to lowa and confront Cummins in the June primary. ${ }^{28}$

The New York Times termed the Brookhart-Cummins contest as a confrontation between "a tried and true Coolidge Republican" and "a LaFollette progressive." The election was to be a litmus test of administration support in the Midwest. Unfortunately for Cummins, farm prices in Iowa had again dropped, following a temporary increase in the presidential election year of 1924 . Wheat which sold for $\$ 1.30$ a bushel in 1924 had

27. Ibid., 5,824, 7,246.

28. Tucker and Barkley, Sons of the Wild Jackass, 364; New York Times, 11 April 1926; George W. Norris to N. Baker, 17 May 1926, "Brookhart Contest in Iowa" file, George W. Norris Papers, Library of Congress, Washington, D.C. (hereafter Norris Papers). 
dropped to $\$ 1.20$ per bushel, while corn had slumped drastically from $\$ .98$ per bushed in 1924 to $\$ .64$ in 1926 . As farm conditions worsened, lowa farmers clamored for passage of the McNary-Haugen bill which would guarantee parity prices for agriculture behind the wall of a protective tariff. But Calvin Coolidge opposed the legislation as price fixing and as an unwarranted government intrusion into business. ${ }^{29}$

In addition to his identification with an increasingly unpopular Coolidge, Cummins had to deal with many observers' impression that, while he had become a Senate insider, he had lost touch with his constituents. Thus George Norris praised his colleague as "one of the most able men in the United States," but regretted that Cummins had slipped away from the progressive cause and had gone over to the opposition. "When a man of the ability and the power of Senator Cummins can be led away from the moorings by the flattery and the alluring inducement of high society, what can you expect of the ordinary person?" Norris lamented. Even Cummins' supporters recognized that he had a problem. Constituent $M$. W. Fitz wrote to Iowa Congressman L. J. Dickinson that Cummins "must turn his head from Easternism or he will be too late to save Iowa from the calamity which it is approaching and [from] Brookhartism, into which we will be so deeply buried, that there will be no reserection [sic] of the Real Republican party." Other Iowans found the spread of Brookhartism a pleasing prospect. E. B. Goss, head of the Corn Growers' Association in Greene County, took Secretary of Agriculture William Jardine to task for the administration's opposition to farm relief: "Do you dare think that you can cram some of your stuff down the farmers' throats and they not come back at you in the polls? Is Brookhart losing out, come to Iowa and see." 30 While Jardine did not have to come to Iowa "and see,"

29. New York Times, 13 April 1926; U.S. Department of Agriculture, Yearbook of Agriculture, 1926 (Washington, D.C., 1927), 804, 834. For an in-depth study of the McNary-Haugen bill see Gilbert C. Fite, George N. Peek and the Fight for Farm Parity (Norman, 1954). A poll by the Des Moines Register, 8 May 1924, showed 926 Iowans in favor of the plan with only 183 opposed.

30. George W. Norris to J. A. Lister, 24 June 1926, Norris Papers; M. W. Fitz to L. J. Dickinson, 9 November 1925, General Records of the Department of Agriculture, Record Group 16, National Archives, Washington, D.C. 
Brookhart did return to the state in 1926, with a new campaign issue which the Senate had handed to him. Cummins had not spoken out when the Senate ignored Iowa election law, and so deprived lowa voters, through political manipulation, of their legally elected representative. Cummins basically campaigned from Washington, while Brookhart "lizzied" into every county, gave sometimes as many as fifteen speeches in a day, and worked until midnight most evenings. He refused to apologize for any of his actions in Washington and promised to continue his aggressive tactics on behalf of farm legislation. He concluded his speeches with the refrain, "I told the truth and they kicked me out." Agrarian discontent with Cummins, and Brookhart's strategy of running as an outsider against the Senate, contributed to an impressive victory for Brookhart, who outpolled Cummins by over 17 percent of the 420,000 votes cast in the primary. Brookhart's was the triumph of a constituency-oriented outsider over a well-respected member of the Senate inner club who followed institutional folkways and norms. After this victory, however, Brookhart took care not to test the Iowa electorate's norm of Republican voting. The party even appeared to make some overtures to Brookhart; for the first time he was asked to deliver a speech at the state party convention. Yet when Cummins died on July 30, Brookhart was not the party's choice to fill the unexpired short session of Cummins' term. This time he did not reply to the party snubbing, but retained his Republican label and rolled to an easy win over his Democratic opponent. He seemed to go out of his way to avoid reminding voters of his 1924 flirtation with the LaFollette campaign. Robert M. LaFollette, Jr. wrote to Ira Lorenz that, "as the matter now stands, I am not going to assist in the Brookhart campaign. This for your own confidential information. Although I was ready and willing to go, Brookhart and his managers decided that my coming would not be helpful to him." With the senior LaFollette dead, Brookhart saw no reason to utilize the son and raise the ghosts of past campaigns. ${ }^{31}$

31. New York Times, 13 June 1926; Neprash, Brookhart Campaigns in Iowa, 57; Robert M. LaFollette, Jr., to Ira Lorenz, 26 May 1926, "Personal Correspondence, 1926" file, Robert M. LaFollette, Jr. Papers, Library of Congress, Washington, D.C. 
Reassuming his position in the Senate, Brookhart continued to serve as a vocal spokesman for the cause of agriculture. While still in the legislative capacity of an outsider, Brookhart did remain a regular Republican in the presidential campaign of 1928, and endorsed Herbert Hoover's candidacy even though the Democratic platform included a plank favorable to the principles of McNary-Haugenism. The New York Times maintained that Brookhart had learned the lesson of party discipline from the voters in 1924 and from the Senate in 1926. The Times believed Brookhart was "pacified, tame and regular." While certainly the legacy of the 1924 election may have had some effect on Brookhart, as an ardent prohibitionist he would not have been favorably disposed toward Hoover's opponent, the "wet" Al Smith. Brookhart also shared with Hoover a native Iowan's heritage and an adherence to the principles of cooperative marketing in their approach to the farm problem. ${ }^{32}$

During Hoover's presidency, agricultural conditions continued to deteriorate and, in 1932, Brookhart's senatorial career would again depend on the voters, the ultimate test for the outsider. Elder progressive statesman George Norris endorsed Brookhart's reelection. Norris wrote to farm spokesman and radio personality Henry Field urging him not to enter the Republican primary and thus split the progressive vote. Norris referred to Brookhart as "courageous and active" in the interests of agriculture. In reply, Field agreed that Brookhart had indeed been a vocal proponent of agrarian discontent but he questioned the Iowa senator's legislative effectiveness: "But the complaint is that he had accomplished nothing whatsoever with his legislative prosials [sic]. They admire you because you have accomplished something, but Senator Brookhart hasn't seemed to put his proposals over." Norris tried to dissuade Field. He pointed out that the progressive group in the Senate had opposed President Hoover on agricultural policy, which incurred the wrath of the regular element in the Republican

32. Smith W. Brookhart, "The Plight of the Farmer," Nation 122 (April 7, 1926), 367-368; New York Times, 4 July 1928; Gilbert C. Fite, "The Agricultural Issue in the Presidential Campaign of 1928," Mississippi Valley Historical Review 37 (March 1951), 653-672; Gary H. Koerselman, "Secretary Hoover and National Farm Policy: Problems of Leadership," Agricultural History 51 (April 1977), 378-395. 
party, an element which "uses all the means known to political machines to defeat us." The progressives were a small minority confronting the vast forces of vested wealth. "Our fights are made against the same odds, and we meet defeat necessarily oftener than we obtain a victory." Norris confirmed that nonconformist senators deserved measurement by a different yardstick that that used to judge the cooperative majority. They might not be effective with their own legislation but could speak for underrepresented interests and further the process of conflict resolution. ${ }^{33}$

In 1922, to some extent in 1924, and in 1926 the Iowa electorate had selected Brookhart as its senator because he would aggressively draw attention to farm distress. By 1932, however, lowans were apparently growing impatient and demanded results. Field defeated Brookhart in the Republican primary, but Franklin Roosevelt's Democratic landslide swept away the Republican stronghold of Iowa and Field lost as well. Merely publicizing agrarian difficulties rather than legislatively solving them no longer satisfied Iowa voters and they banished the flamboyant Brookhart to private life. Although he became an FDR supporter, Brookhart was never able to adjust to the crop reduction programs of the New Deal. He maintained at one point that for the government to carry out a program of acreage restriction it would be necessary to kill off at least 20 percent of the farm population. He never again held an elective public office and, except for a brief stint as a Special Trade Adviser on Russia for the Department of Agriculture, he remained in private law practice until his death in $1944 .^{34}$

Examination of Smith Brookhart's political career lends credence to the idea that a senator may circumscribe Senate norms and folkways successfully by interpreting the senatorial role in terms of policy and constituency rather than institutional goals. Brookhart was not concerned with his reputation in the Senate as long as he could hold forth on the virtues of cooperative marketing and satisfy the Iowa electorate. Brookhart's career also provides an interesting illustration of the limita-

33. George W. Norris to Henry Field, 11, 16 April 1932, Henry Field to George Norris, 13 April 1932, Norris Papers.

34. John D. Hicks and Theodore Saloutos, Twentieth Century Populism: Agricultural Discontent in the Middle West, 1900-1939 (Madison, 1951), 419. 
tions of senatorial sanctions. The Senate took no official action against Brookhart for his irregular conduct during his first term, but from 1924 to 1926, when an opportunity arose to express its disapproval of the Iowan, the Senate was not reluctant to deny Brookhart committee assignements and, finally, his seat in the chamber. The Senate will apply sanctions, but such action takes place only under somewhat extraordinary circumstances. Both the Iowa voters and the Senate had little patience for Brookhart's flirtation with the LaFollette campaign, which suggests that party regularity may be a more important legislative norm than some political scientists have believed it to be. But Senate condemnation by itself was not capable of destroying Smith Brookhart's political career. Iowans returned him to the Senate in 1926, and only their repudiation in 1932 cut short his colorful senatorial career. The dissenter in the Senate, as the case of Smith W. Brookhart indicates, may disregard Senate norms and, on occasion, Senate sanctions, if still fulfilling the needs and desires of the constituency back home. 
Copyright of Annals of Iowa is the property of State of Iowa, by \& through the State Historical Society of Iowa and its content may not be copied or emailed to multiple sites or posted to a listserv without the copyright holder's express written permission. However, users may print, download, or email articles for individual use. 